\section{BRS Kurumi and BRS Capiaçu - New elephant grass cultivars for grazing and cut-and-carry system}

\section{Antônio Vander Pereira ${ }^{1}$, Francisco José da Silva Lédo ${ }^{1}$ and Juarez Campolina Machado ${ }^{1^{*}}$}

\begin{abstract}
Cultivar BRS Kurumi is characterized by short plant height, short internodes, high dry matter production (29.25 tha $\left.^{-1} \mathrm{r}^{-1}\right)$, has a high nutritional value and is recommended for the cut-and-carry system or grazing. Cultivar BRS Capiaçu, indicated for silage and the cut-and-carry system, has tall upright growth, high dry matter production (49.75 $t$ ha $^{-1} \mathrm{yr}^{-1}$ ), good forage quality, is lodging-resistant and suitable for mechanical harvesting. Both cultivars are vegetatively propagated by stem cuttings.
\end{abstract}

Key words: Pennisetum purpureum, plant breeding, cultivars, forage traits.

\section{INTRODUCTION}

Elephant grass (Pennisetum purpureum Schum.) is one of the most important forages, grown in almost all tropical and subtropical regions of the world. This forage stands out for its high dry matter production potential, forage quality, palatability, vigor, and persistence. It is mainly used in cut-and-carry system, and can also be used for silage and rotational grazing (Pereira et al. 2001).

Milk and meat production in Brazil are based on the use of pastures. However, these are strongly influenced by seasonal variations in forage supply, with negative consequences for animal production. Elephant grass is a low cost alternative for roughage supply, with positive effects on pasture stocking rate (Cóser et al. 2000).

In 1991, Embrapa Gado de Leite initiated a breeding program of this forage, addressing the development of cultivars for cut-and-carry system and grazing. To this end, the Germplasm bank of Elephantgrass (BAGCE) was established, with 110 accessions introduced from different regions of Brazil and abroad. The accessions were described based on morphological, cytogenetic and molecular descriptors (Shimoya et al. 2001, Techio et al. 2006, Pereira et al. 2008), and agronomic evaluations were carried out, underlying the selection of genetically divergent accession with high forage value for the breeding program. New genotypes were developed by controlled crosses and evaluation, selection and cloning of the best progenies, followed by clonal performance tests in different environments.

Cultivar BRS Kurumi, destined for grazing, and BRS Capiaçu, for silage and cutand-carry feeding, represent the most recent cultivars of this breeding program.
Crop Breeding and Applied Biotechnology 17: 59-62, 2017 Brazilian Society of Plant Breeding. Printed in Brazil http://dx.doi.org/10.1590/198470332017v17n1c9 


\section{CULTIVAR BRS KURUMI}

\section{Breeding Methods}

To breed short cultivars appropriate for grazing, several crosses were carried out between the normal-sized accessions selected from BAGCE and accessions carrying the dwarf gene. This recessive gene, in homozygous condition, causes a shortening of the stem internodes, thus reducing plant height (Sollenberger et al. 1988). Consequently, the leaf/stem ratio increases significantly and the forage quality is improved, since the nutritional value of the leaves is higher than that of the stems.

The BAGCE accessions carrying the recessive dwarf gene (Merkeron de Pinda and Mott) were used as parents in crosses to breed short-height progenies. The accession Merkeron de Pinda has a normal height, since its genotypic background is heterozygous for the dwarf gene, while the homozygous accession Mott has a short plant height.

Cultivar BRS Kurumi was derived from a cross between the accession Merkeron de Pinda (BAGCE 19) and Roxo (BAGCE 57). The $F_{1}$ progenies of this cross had a tall size and the best were selected and recombined by polycross. The resulting progeny segregated for tall and short-height green and purple plants. Cultivar BRS Kurumi was obtained by selection and cloning of one of the short and green progenies.

Tests for the Value for Cultivation and Use (VCU) were performed for the Atlantic Forest, Amazon and Cerrado biomes, where this cultivar is recommended for cultivation. Cultivar BRS Kurumi was released by Embrapa in partnership with the Empresa de Pesquisa Agropecuária de Santa Catarina - Epagri, Agência Paulista de Tecnologia dos Agronegócios - Apta and Universidade Estadual do Norte Fluminense Darcy Ribeiro - Uenf.

\section{Cultivar characteristics}

Cultivar BRS Kurumi is a vegetatively propagated, perennial, short-height clone, recommended for the cut-andcarry system and for grazing. This cultivar is characterized by semi-open clumps, green leaves and stems, short internodes (mean of $4.8 \mathrm{~cm}$ ) and mean height of $70 \mathrm{~cm}$ during the growing season (Figures 1 and 2, Table 1).

This cultivar has vigorous vegetative growth, rapid leaf expansion and intense basal and axillary tillering. Flowering occurs from June to July, and at this stage the stem is elongated and the plant can grow up to $3 \mathrm{~m}$ tall. The cultivar is propagated by vegetative cuttings resulting from stem subdivision, and the gems have excellent germination capacity.

According to Gomide et al. (2011), cultivar BRS Kurumi has a potential dry matter (DM) production of $29.25 \mathrm{t}$ ha ${ }^{1} \mathrm{yr}^{-1}$, of which $70 \%$ is concentrated in the rainy season. Compared to the short-height cultivar Mott, BRS Kurumi had a higher dry matter production of forage and leaves, as well as more axillary and basal tillers. In an experiment conducted over five grazing periods, from November 2001

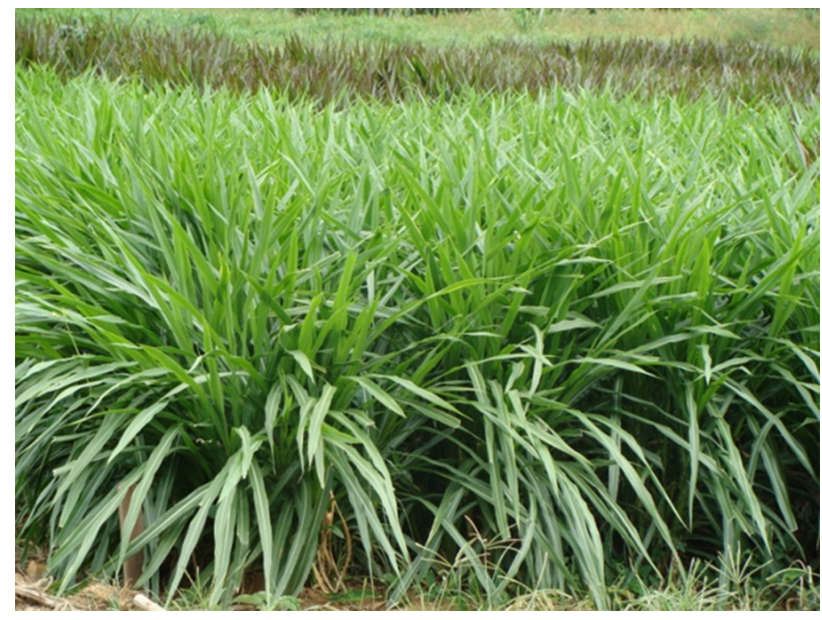

Figure 1. BRS Kurumi, low plant height cultivar for rotational grazing.

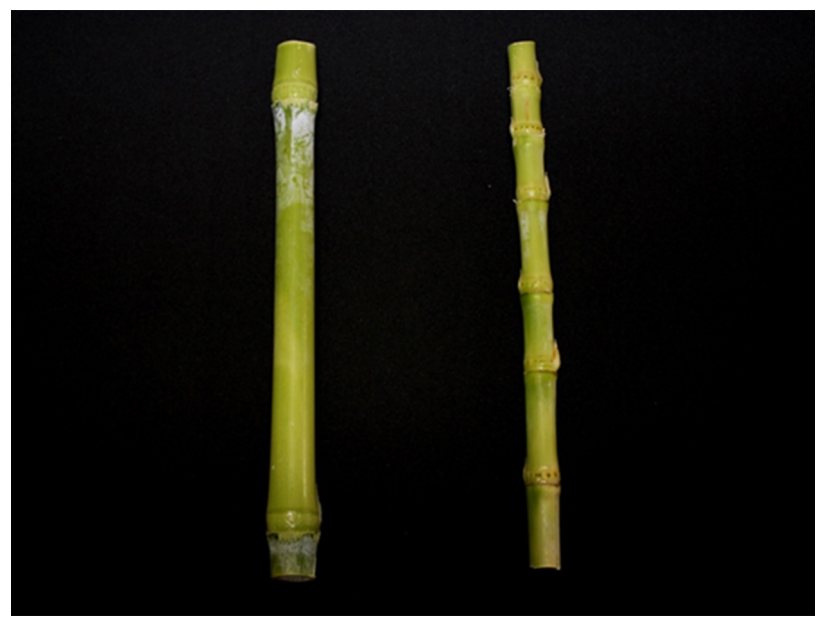

Figure 2. Comparison of internode length of BRS Capiaçu (tall plant) and BRS Kurumi (dwarf plant). 
to June 2002, BRS Kurumi produced $16.2 \mathrm{t} \mathrm{ha}^{-1}$ forage DM and $11.1 \mathrm{t} \mathrm{ha}^{-1}$ leaf DM; while cultivar Mott produced $7.7 \mathrm{t}$ ha $^{-1}$ and $7.1 \mathrm{t} \mathrm{ha}^{-1}$, respectively. Almeida et al. (2004) observed growth of 36 and 24 basal tillers per $\mathrm{m}^{2}$ and 96 and 66 axillary tillers per $\mathrm{m}^{2}$ for the cultivars BRS Kurumi and Mott, respectively. Similarly, Gomide et al. (2015) observed that cultivar BRS Kurumi had higher volumetric forage and leaf density than the tall cultivar Napier.

Aside from the ease of management for grazing compared to normal-sized cultivars, BRS Kurumi has a high production of forage with high nutritional value. Crude protein (CP) content in the forage reaches $18-20 \%$ and the in vitro dry matter digestibility (IVDMD) varies around 70\% (Gomide et al. 2015).

Cultivar BRS Kurumi is susceptible to Mahanarva spectabilis, and is not recommended for cultivation in areas with a history of high pasture spittlebugs infestation. It was registered by the Ministry of Agriculture, Livestock and Supply (MAPA) on 04/17/2012 (No. 28690), and was licensed by the plant variety protection certificate on $02 / 02 / 2012$ (No. 20120164), while Embrapa holds the property rights of this cultivar. Embrapa Gado de Leite is responsible for the maintenance of the genetic stock of this cultivar and information about propagation material can be requested from Embrapa Produtos e Mercado, agency in Brasilia-DF (www.embrapa.br/produtos-e-mercado).

\section{CULTIVAR BRS CAPIAÇU}

\section{Breeding methods}

Cultivar BRS Capiaçu was developed from a cross made in 1992, between the accessions Guaco (BAGCE 60) and Roxo (BAGCE 57). The full-sib seeds from this cross were sown in beds, since strong segregation for forage-related traits had been observed. The 10 best progenies of this family were cloned for comparative tests with clones selected from other crosses. The selected clones were evaluated by the national network of elephant grass evaluation (RENACE) in 17 Brazilian states, from 1999 to 2008 (Pereira and Lédo 2008). From 2009 to 2011, clone CNPGL 92-79-2 was tested for the value of cultivation and use (VCU), and registered and protected as BRS Capiaçu.

\section{Cultivar characteristics}

Cultivar BRS Capiaçu was developed by the Embrapa breeding program of elephant grass. This cultivar is characterized by late flowering; tall size; upright clumps, leaves with wide, long and green blades; yellowish green leaf sheath and; stem with thick diameter and yellowish internodes (Table 2 and Figure 3).

This cultivar is distinguished by high yield and forage quality (Table 3 ); high lodging resistance and by excellent adaptation to mechanical harvest.

BRS Capiaçu also produces good quality silage, representing a cheaper alternative than corn, for being a
Table 1. Main traits of cultivar BRS Kurumi

\begin{tabular}{|c|c|}
\hline Traits & Description \\
\hline Plant material & Clone \\
\hline Ploidy level & Tetraploid $(2 \mathrm{n}=4 \mathrm{x}=28)$ \\
\hline Cultivation & Vegetative propagation (stem cuttings) \\
\hline Flowering period & June - July \\
\hline Growth habit & Clumps (semi-open clump) \\
\hline Basal tiller density & High (36 tillers $\mathrm{m}^{-2}$ ) \\
\hline Axillary tiller density & High (96 tillers $\mathrm{m}^{-2}$ ) \\
\hline Plant height & $70 \mathrm{~cm}$ \\
\hline Stem diameter & $1.2 \mathrm{~cm}$ \\
\hline Internode length & $4.8 \mathrm{~cm}$ \\
\hline Leaf/stem ratio ${ }^{1}$ & 11.8 \\
\hline Leaf width & $3.4 \mathrm{~cm}$ \\
\hline Leaf length & $69 \mathrm{~cm}$ \\
\hline Leaf color & green \\
\hline Midrib color & white \\
\hline Total dry matter production & $20.2 \mathrm{t} \mathrm{ha}^{-1} \mathrm{yr}^{-1}$ \\
\hline Crude protein $(\mathrm{CP})^{1}$ & $20.6 \%$ \\
\hline Digestibility (IVDMD) ${ }^{1}$ & 67.6 \\
\hline
\end{tabular}

${ }^{1}$ Summer (harvest after 20 days).

Table 2. Main traits of cultivar BRS Capiaçu

\begin{tabular}{|c|c|}
\hline Trait & Description \\
\hline Plant material & Clone \\
\hline Ploidy level & Tetraploid $(2 n=4 x=28)$ \\
\hline Cultivation & Vegetative propagation (cuttings) \\
\hline Flowering period & Late (June - July) \\
\hline Growth habit & Clumps (upright clump) \\
\hline Basal tiller density & Medium (30 tillers $\mathrm{m}^{-2}$ ) \\
\hline Plant height & Tall $(4.20 \mathrm{~m})$ \\
\hline Stem diameter & Thick $(1.6 \mathrm{~cm})$ \\
\hline Internode length & $16 \mathrm{~cm}$ \\
\hline Leaf/stem ratio & 0.75 \\
\hline Leaf width & $5.17 \mathrm{~cm}$ \\
\hline Leaf length & $106 \mathrm{~cm}$ \\
\hline Leaf color & Green \\
\hline Midrib color & White \\
\hline Total forage yield $\left(\mathrm{t} \mathrm{ha}^{-1} \mathrm{yr}^{-1}\right)$ & 49.75 \\
\hline Leaf yield ( $\left.\mathrm{t} \mathrm{ha-1} \mathrm{yr}^{-1}\right)$ & 21.60 \\
\hline Crude protein (\%) - Whole-plant content & 9.10 \\
\hline IVDMD (\%) - Whole-plant content & 54.76 \\
\hline Fiber NDF (\%) - Whole-plant content & 71.5 \\
\hline
\end{tabular}


Table 3. Total dry matter production (TDMP), leaf dry matter production (LDMP) and crude protein (CP) content

\begin{tabular}{lccc}
\hline Cultivars & Annual TDMP $\left(\mathrm{t} \mathrm{ha}^{-1}\right)$ & Annual LDMP $\left.(\mathrm{t} \mathrm{ha})^{-1}\right)$ & Whole-plant CP content $(\%)$ \\
\hline BRS Capiaçu & 49.75 & 21.60 & 9.10 \\
Mineiro & 36.79 & 16.16 & 6.94 \\
Cameroon & 29.87 & 14.32 & 7.17 \\
\hline
\end{tabular}

perennial crop that does not require annual seed purchase and with higher productivity.

The cultivar has vegetative propagation by cuttings and is indicated for forage cutting, destined for roughage supply in the form of silage or cut-and-carry system. The elephant grass cultivar BRS Capiaçu was registered by MAPA on 01/08/2015 (No. 33503), and licensed by a cultivar protection certificate on $01 / 23 / 2015$ (No.20150009), whereas Embrapa maintains the property rights of the cultivar. Based on results of VCU tests, this cultivar is recommended for cultivation in the Atlantic Forest biome. The genetic stock of BRS Capiaçu is maintained by Embrapa Gado de Leite and information on propagation material can be obtained at Embrapa Produtos e Mercado, agency in Brasília-DF (www.embrapa.br/produtos-e-mercado).

\section{REFERENCES}

Almeida EX, Baad EAS and Pereira AV (2004) Avaliação de novos genótipos de capim-elefante sob pastejo. Agropecuária Catarinense 17: 75-78.

Cóser AC, Martins CE and Deresz F (2000) Capim-elefante: formas de uso na alimentação animal. Embrapa, Juiz de Fora, 27p. (Circular Técnica, 57).

Gomide CA, Paciullo DSC, Ledo FJ S, Pereira AV, Morenz MJF and Brighenti AM (2015) Informações sobre a cultivar BRS Kurumi. Embrapa, Juiz de Fora, 4p. (Comunicado Técnico, 75).

Gomide CAM, Paciullo DSC, Ledo FS, Castro CRT and Morenz MJF (2011) Produção de forragem e valor nutritivo de clones de capim-elefante anão sob estratégias de desfolha intermitente. Embrapa, Juiz de Fora, 23p. (Boletim de Pesquisa e Desenvolvimento, 31).

Pereira AV and Lédo FJS (2008) Melhoramento genético de Pennisetum purpureum. In Resende RMS, Valle CB and Jank L (eds) Melhoramento de forrageiras tropicais. Embrapa, Campo Grande, p. 89-116.

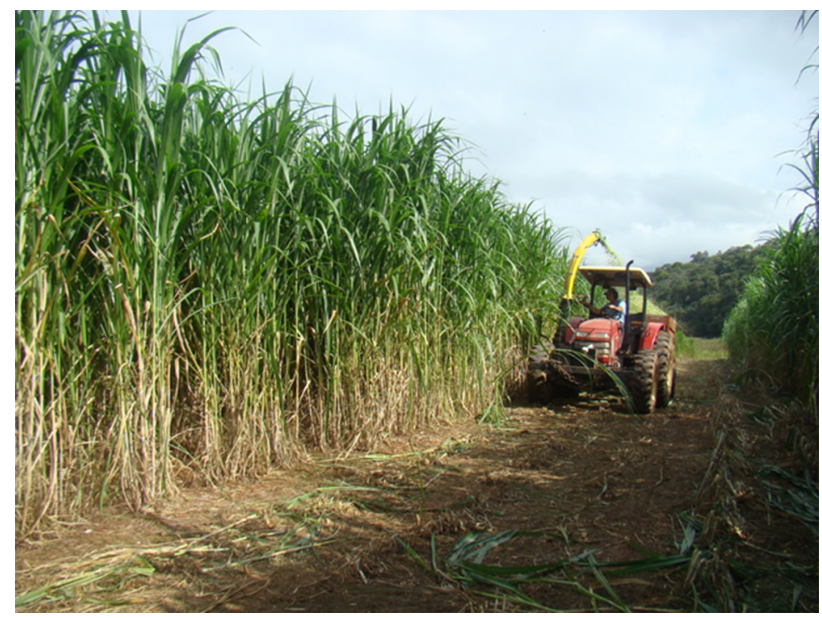

Figure 3. BRS Capiaçu - elephant grass cultivar for production of silage or cut-and-carry system.

Pereira AV, Machado MA, Azevedo ALS, Nascimento CS, Campos AL and Ledo FJS (2008) Diversidade genética entre acessos de capim-elefante obtida com marcadores moleculares. Revista Brasileira de Zootecnia 37: 1216-1221.

Pereira AV, Valle CB, Ferreira RP and Miles JW (2001) Melhoramento de forrageiras tropicais. In Nass LL, Valois ACC, Melo IS and Valadares Inglis MC (eds) Recursos genéticos e melhoramento. Fundação MT, Rondonópolis, p. 549-602.

Shimoya A, Ferreira RP, Pereira AV, Cruz CD and Carneiro PCS (2001) Comportamento morfo-agronomico de genótipos de capim-elefante. Revista Ceres 48: 1-19.

Sollenberger LE, Prine GN, Ocumpaugh WR, Hanna WW, Jones Jr. CS, Schank SC and Kalmbacher RS (1988) Mott elephantgrass: a high quality forage for the subtropics and tropics. (s.p.): Florida Agricultural Experimental Station, 18p. (Circular, 5-356).

Techio VH, Davide LC and Pereira AV (2006) Meiosis in Pennisetum purpureum, P. glaucum and interspecific hybrids (Poaceae, Poales). Genetics and Molecular Biology 29: 253-262. 